\begin{tabular}{c} 
Volume and Issues Obtainable at Center for Sustainability Research and Consultancy \\
Journal of Business and Social Review in Emerging Economies \\
ISSN: 2519-089X (E): 2519-0326 \\
Volume 6: Issue 2 June 2020 \\
ᄃSR \\
Journal homepage: $\underline{\text { www.publishing.globalcsrc.org/jbsee }}$ \\
\hline
\end{tabular}

\title{
An Assessment of Public Opinion in Balochistan about Federal Form of Government in Pakistan
}

\section{${ }^{1}$ Abdul Basit Khan, ${ }^{2}$ Ali Shan Shah, ${ }^{3}$ Tariq Aziz, ${ }^{4}$ Mian Muhammad Azhar}

${ }^{1 \& 2}$ Assistant Professor, Department of Political Science \& IR, Government College University, Faisalabad, Pakistan, ${ }^{3}$ Ph.D. Scholar, Department of Political Science \& IR, Government College University, Faisalabad, Pakistan,

${ }^{4}$ Assistant Professor, Department of Political Science \& IR, Government College University, Faisalabad, Pakistan, muhammad.azhar@gcuf.edu.pk

\section{ARTICLE DETAILS \\ History \\ Revised format: May 2020}

Available Online: June 2020

\section{Keywords}

Balochistan, Pakistan, Federal

Form of Government, Empirical

Analysis, Field Survey

JEL Classification

M0, M12

\begin{abstract}
Almost every state or society particularly a pluralistic one is composed of various nationalities or sub-national groups whereas every segment has its own distinct identity being a source of pride and strength for its survival. In relatively homogenous societies, the process of nation-building though not easy is at least less cumbersome whereas in pluralistic societies this process demands a lot of hard work on the part of the elite who must exhibit vision, wisdom, foresight and patience; because such societies are always fraught with the danger that any of the nationalities or sub-national group may dominate the others. The societies having a considerable level of social, cultural and linguistic heterogeneity hence horizontally/vertically divided and cross-divided in the pursuit of their distinct preferences and priorities can hardly be united under a single administrative structure nevertheless they can be persuaded to form a union under some common government. For this purpose, a federal arrangement may be suitable option because it provides for unity in diversity rather than unity in its absolute terms. The federation of Pakistan, since its vey inception, is struggling to create the said unity particularly with reference to the situation in Balochistan which is facing a long and multi-faceted unrest posing a substantial challenge for the federation. The present study empirically explores the nature of grievances of the people of Balochistan with respect to the federation of Pakistan by conducting a field survey and establishes that majority of the people of Balochistan do not believe that the federal design in Pakistan is functioning in its true letter and spirit with reference to Balochistan.
\end{abstract}

(C) 2020 The authors, under a Creative Commons AttributionNonCommercial 4.0

\section{Corresponding author's email address: muhammad.azhar@gcuf.edu.pk}

Recommended citation: Khan, A. B., Shah, A. S., Aziz, T., and Azhar, M. M. (2020). An Assessment of Public Opinion in Balochistan about Federal Form of Government in Pakistan. Journal of Business and Social Review in Emerging Economies, 6(2), 703-713

\section{Introduction}

The federal form of government is considered to be suitable for developing countries because it can persuade the 
contending parties and social groups to form a common platform for achieving peace, harmony and progress in the society; however, in some countries it may encourage the entrenched and built-in centrifugal tendencies (Ali, 1988). Under this system, small states may join a more powerful commonwealth to obtain certain manifest advantages (both internal and external) which flow from the union without, at the same time, wholly surrendering their separate existences and sacrificing their right to govern themselves with respect to matters which concern them alone. It, thus, combines the advantages of national unity with those of local autonomy and the right of self-government. In return for this advantage, the people delegate authority to the federal government to regulate certain affairs of general interest concerning all the states constituting the union. It furnishes the means of maintaining equilibrium between the centrifugal and centripetal forces in a state of widely different tendencies.

The elite of some developing countries are prone to an irresistible tendency to skip the transitional period of adjustment and jump straightly to a centralized system of government which often accentuates bitterness and rivalry among the constituting units of a federation. According to Hicks et al, in most of the new states, whether large or small, federations or otherwise, the compulsion of nationalism brought a very high degree of centralization. The most significant pressures to such societies are socialist ideologies, national economic planning, the quest of the elite for total solidarity, one-party system paving the way to dictatorship, and prolonged emergency governments resulting from insurrection and civil disturbances; hence under such unfavorable environment, federalism clearly would have to struggle for survival (Hicks et al, 1961). The true spirit of federalism demands that the units must be allowed to enjoy maximum possible autonomy and all the sub-national identities should be incorporated into the decision making process at federal level. A happy co-ordination between the federal and regional governments is possible only after a specific constitutional demarcation of areas of their respective jurisdiction. The federal government should not undermine the regional autonomy of any of its constituting unit. The political map of the country should be drawn or redrawn in a way that the local urges and aspirations of the people for having a separate state of their own are reconciled with the over-all requirements of national integration. People should learn that the interests of the nation as a whole over-ride their primordial loyalties.

Pakistan is also one of those pluralistic societies in which the contending nationalities and sub-national groups are not only divided rather cross-divided on horizontal and vertical levels; hence, there is a dire need that the peculiarities of such contending groups should be recognized and accommodated through a welldesigned, representative and genuinely federal arrangement (based on coordination/cooperation rather than subordination) suitable to its peculiar and objective conditions. The country never enjoyed transfer of any of substantial administrative powers to the constituting units thus negating the very essence of federalism; which failure has resulted in its dismemberment and constant rebellions. The province of Balochistan has a long history of political turmoil since the very inception of Pakistan as an independent country. In the pages to come, we will try to apply the abovementioned theoretical framework to the federation of Pakistan with respect to the prevailing ground realities in Balochistan.

\section{The Case of Balochistan in the Federal Setup of Pakistan}

Balochistan comprised almost two fifth (43.6\%) of the whole of Pakistan with an area of 134050 sq. miles (347190 sq. km.); it is larger than the collective area of Punjab and Sind. It is sparsely populated (81,90,000 as estimated in 2007). Only 5\% of the total population of Pakistan lives in Balochistan with per sq. km. density of only 18.9 i.e. the lowest in Pakistan. Quetta is the most populated city with 0.872 million inhabitants. Only Khuzdar, Turbat and Chaman are the other cities with a population numbering over 50,000 (Pakistan Bureau of Statistics, Government of Pakistan, 1998)

Balochistan is a multiethnic province with majority of the Pashtuns in districts of Pishin, Killa Abdullah, Loralai, Killa Saifullah, Musakhel, Zhob and Ziarat. People from Sind and Siraiki regions are residing in the districts of Jhal Magsi, Lasbella, Jaffar Abad, Nasir Abad and Bolan. The Balochs constitute majority in the districts of Chagi, Kohlu, Dera Bugti, Kalat, Khuzdar, Awaran, Kharan, Kech, Gawader and Panjgur (Breseeg, 2004).). Because of the influx of Pashtun refugees from Afghanistan, the demography of Balochistan has drastically been changed and the Balochs are now no longer the dominant ethno-linguistic group in large parts of the province. Moreover, a significant number of Balochs had also been assimilated in South Punjab and Sindh. Despite the distinct traditional culture of Balochistan, the Balochs are relatively weaker in their organization. 
In its report of 2003, the United Nations Development Program (UNDP) indicated that Balochistan was at the bottom in almost all human development indices when compared to other federating units of Pakistan. All indicators of the socio-economic growth and human development (health, literacy, etc.) established the backwardness and underdevelopment of Balochistan province. About $48 \%$ people of Balochistan were living below poverty line while in Punjab this figure was only $26 \%$. Literacy rate in Balochistan always lagged behind the national average. The overall literacy rate is $24 \%$ which is the lowest while it is only $5 \%$ within females. In 1981, it was $10 \%$ while the national average was 26\%. In 2004-5, literacy rate in Balochistan was the lowest (37\%) when compared to other provinces (Sindh 56\%, Punjab 55\%, NWFP (KPK) 45\%) and the national average of 53\%. During 1973-2000, Gross Domestic Product (GDP) growth rate in Balochistan showed a decline while the GDP in Sindh and Punjab increased at a rate of $2 \%$ (Jetly, 2006).

\section{Theme and Methodology of the Field Survey and Break-up of Respondents}

To understand the view of the general public of Balochistan about functioning of the federal form of government, a survey was designed to ask the people of Balochistan about some basic issues. Since these issues were rather technical in nature, therefore, the universe of the survey comprised only the educated members of the community from public sector universities within or outside Balochistan, the urban population of Quetta and other major district headquarters of Balochistan along with the people of Balochistan settled in Islamabad. The questionnaire was circulated among one thousand people having domicile of Balochistan. Out of these one thousand questionnaires, 700 were distributed among males and 300 were distributed among females. The total feedback collected was of 571 respondents out of which the number of male respondents was 461 whereas of female respondents was 110 . The ratio of male respondents to the total respondents was $80.7 \%$ and of female respondents to the total respondents was $19.3 \%$. The ratio of female respondents was much less than that of male respondents (almost 1 to 4) due to the fact that the people of Balochistan are a community where access of male members to the female members is limited even in the case of family members. Their access to education is also limited as compared to male members. Therefore, the number of female respondents is below par. Age-wise breakup of total respondents was such that, out of 571 respondents, 219 were below 25 years of age which constituted $38.4 \%$ of the total respondents. The number of respondents who were below 35 years of age was 185 which constituted $32.4 \%$ of total respondents. 122 respondents were below 45 years of age, constituting $21.4 \%$ of total respondents. The total number of respondents with 45 years of age or above was 45 i.e. $7.9 \%$ of the total respondents.

The language-wise breakup of respondents was such that a total of 249 respondents had Balochi as their first language which constituted $43.6 \%$ of the total respondents. 118 respondents had Brahui as their first language constituting $20.7 \%$ of the total respondents. 142 respondents had Pashto as their first language which constituted $24.9 \%$ of the total respondents. The number of respondents having Urdu as their first language was 35 which constituted $6.1 \%$ of the total respondents. 27 respondents had some other first language; such people were $4.7 \%$ of the total respondents.

\subsection{Details of the Feedback}

To make the study more precise and comprehensive, we will present and analyze the question-wise feedback of the survey in the pages to come, keeping in view only the first language of the respondents. It would be pertinent to mention that each question of the survey had three options; the respondent might agree or disagree with the statement of question; he or she also had the option to remain indifferent about any particular issue.

\subsubsection{Provincial Autonomy}

Over-centralized political power had remained a constant problem for the political system of Pakistan. Mohammad Ali Jinnah, the first Governor-General of Pakistan, amended the Government of India Act (adopted), 1935, making it more unitary and less federal while the Pakistan Resolution of 1940 envisaged for greater regional autonomy in Pakistan. Moreover, internal autonomy for the federating units had also been promised by various constitutional instruments promulgated so far in Pakistan. This autonomy, nevertheless, remained a contested issue because of the highly centralized authority exercised by the federal government. Some scholars even believe that the failure of the political elite to address the issue resulted in the disintegration of Pakistan in 1971. The intelligentsia from Balochistan often complains that the province has been deprived of the autonomy as desired and enjoyed by other federating units. The first question investigated whether or not the educated citizenry of the province feels itself 
administratively autonomous.

\begin{tabular}{|c|c|c|c|c|c|c|}
\hline \multicolumn{6}{|c|}{ Do you agree that the present constitutional structure of Pakistan is providing sufficient internal autonomy to Balochistan? } & \multirow[b]{2}{*}{ Total } \\
\hline & & & Agreed & Disagreed & Indifferent & \\
\hline \multirow{10}{*}{$\begin{array}{l}\text { First Language of the } \\
\text { Respondents }\end{array}$} & \multirow[t]{2}{*}{ Balochi } & Count & 37 & 172 & 40 & 249 \\
\hline & & $\begin{array}{l}\% \text { within first language of the } \\
\text { respondents }\end{array}$ & $14.9 \%$ & $69.1 \%$ & $16.1 \%$ & $100.0 \%$ \\
\hline & \multirow[t]{2}{*}{ Brahui } & Count & 16 & 79 & 23 & 118 \\
\hline & & $\begin{array}{l}\% \text { within first language of the } \\
\text { respondents }\end{array}$ & $13.6 \%$ & $66.9 \%$ & $19.5 \%$ & $100.0 \%$ \\
\hline & \multirow[t]{2}{*}{ Pashto } & Count & 19 & 96 & 27 & 142 \\
\hline & & $\begin{array}{l}\% \text { within first language of the } \\
\text { respondents }\end{array}$ & $13.4 \%$ & $67.6 \%$ & $19.0 \%$ & $100.0 \%$ \\
\hline & \multirow[t]{2}{*}{ Urdu } & Count & 2 & 24 & 9 & 35 \\
\hline & & $\begin{array}{l}\% \text { within first language of the } \\
\text { respondents }\end{array}$ & $5.7 \%$ & $68.6 \%$ & $25.7 \%$ & $100.0 \%$ \\
\hline & \multirow{2}{*}{\begin{tabular}{|l} 
Other \\
Languages
\end{tabular}} & Count & 7 & 18 & 2 & 27 \\
\hline & & $\begin{array}{l}\% \text { within first language of the } \\
\text { respondents }\end{array}$ & $25.9 \%$ & $66.7 \%$ & $7.4 \%$ & $100.0 \%$ \\
\hline
\end{tabular}

\section{Source: Authors' survey}

The analysis of the feedback revealed that in the case of respondents having Balochi as their first language, only $14.9 \%$ expressed satisfaction with the autonomy provided by the present constitutional structure of Pakistan while $69.1 \%$ of such respondents were dissatisfied in that respect; the ratio of indifference remained $16.1 \%$ within these respondents. Moreover, only $13.6 \%$ of the Brahui, $13.4 \%$ of the Pashto, 5.7\% of the Urdu speaking respondents and $25.9 \%$ of respondents having some other first language expressed satisfaction with the extent of regional autonomy whereas $66.9 \%$ of the Brahui, $67.6 \%$ of the Pashto, $68.6 \%$ of the Urdu speaking respondents and $66.7 \%$ of respondents having some other first language dissatisfied in that regard. The ratio of indifference remained $19.5 \%$ within the Brahui, 19.0\% within the Pashto, 25.7\% within the Urdu speaking respondents and 7.4\% within respondents having some other first language. We may summarize that a clear majority of the respondents, irrespective of their linguistic affiliation, was dissatisfied with the extent of autonomy provided to Balochistan by the constitution of Pakistan.

\subsubsection{Performance of Bureaucracy}

Bureaucracy is comprised of a large group of people who are involved in running a government but who are not elected. In other words, the executive wing of the government deployed for the policy implementation forms the bureaucracy which plays an important role to harmonize any society. It is generally believed that an ethnically skewed military and civil bureaucracy in Balochistan had reinforced perceptions that the centre secured interests of Punjab at the cost of the smaller federating units. The representation of the Balochs in federal and provincial bureaucracy always remained below par with respect to their numerical strength. The satisfaction level of the people of Balochistan with the performance of the federal and provincial bureaucracy was checked during the field survey.

\begin{tabular}{|l|l|l|c|c|c|c|}
\hline \multicolumn{7}{|c|}{ Do you agree that the provincial and federal bureaucracy is functioning effectively in Balochistan? } \\
\hline
\end{tabular}




\begin{tabular}{|l|l|l|c|c|c|c|}
\hline & \multicolumn{1}{|l}{$\begin{array}{l}\% \text { within first language of the } \\
\text { respondents }\end{array}$} & $7.7 \%$ & $63.4 \%$ & $28.9 \%$ & $100.0 \%$ \\
\cline { 2 - 7 } & Urdu & Count & 6 & 27 & 2 & 35 \\
\hline & $\begin{array}{l}\text { \% within first language of the } \\
\text { respondents }\end{array}$ & $17.1 \%$ & $77.1 \%$ & $5.7 \%$ & $100.0 \%$ \\
\cline { 2 - 7 } & $\begin{array}{l}\text { Other } \\
\text { Languages }\end{array}$ & $\begin{array}{l}\text { Count } \\
\text { \% within first language of the } \\
\text { respondents }\end{array}$ & $7.4 \%$ & $88.9 \%$ & $3.7 \%$ & $100.0 \%$ \\
\hline
\end{tabular}

Source: Authors' survey

Only $6.4 \%$ of the Balochi, $5.9 \%$ of the Brahui, $7.7 \%$ of the Pashto, $17.1 \%$ of the Urdu speaking respondents and $7.4 \%$ of respondents having some other first language were satisfied with the performance of bureaucratic machinery deployed in Balochistan. The ratio of dissatisfaction in that regard was at much higher side which remained $75.9 \%$ within the Balochi, 75.4\% within the Brahui, $63.4 \%$ within the Pashto, $77.1 \%$ within the Urdu speaking respondents and $88.9 \%$ within respondents from other linguistic groups. $17.7 \%$ of the Balochi, $18.6 \%$ of the Brahui, $28.9 \%$ of the Pashto, 5.7\% of the Urdu speaking respondents and 3.7\% of respondents from other linguistic groups remained indifferent. It may safely be concluded that all linguistic factions of Balochistan strongly condemned the performance of provincial and federal bureaucracy.

\subsubsection{NFC Award}

In Pakistan, more than $93 \%$ of the resources of the country are generated by the federal government whereas the contribution of the provinces is almost $7 \%$. The federal government, on the other hand, accounts for almost $70 \%$ of the aggregate national expenditure whereas the remaining $30 \%$ goes to the provinces which naturally have to rely on federal government to meet their expenditures (http://www.finance.gov.pk/nfc/reportofthenfc_2009.pdf). The constitution of Pakistan provides for a National Finance Commission (NFC) Award to decide how to share the revenue among the federating units. Until 2009, population of the province was the primary criterion to decide the share of the respective unit nevertheless the Award was modified in December 2009 providing that the onward distribution of the divisible pool would be based on 82 per cent weightage to population, 10.3 per cent to poverty, 2.5 per cent to revenue generation, 2.5 per cent to revenue collection and 2.7 per cent to area of the respective unit (7th NFS Award Signed in Gwadar, 2009). The intention was that the underdeveloped regions could get more revenues hence Balochistan had an increased share under the 7th NFC Award (2009). When the people of Balochistan were asked whether or not the said NFC Award managed to reduce the complaints of the people of Balochistan, a mixed response was observed.

\begin{tabular}{|c|c|c|c|c|c|c|}
\hline \multicolumn{6}{|c|}{$\begin{array}{c}\text { Do you agree that the increased share of Balochistan in } 7^{\text {th }} \text { National Finance Commission Award (2009) succeeded to reduce the } \\
\text { frustration/deprivation level so far complained of by the people? }\end{array}$} & \multirow[b]{2}{*}{ Total } \\
\hline & & & Agreed & Disagreed & Indifferent & \\
\hline \multirow{10}{*}{$\begin{array}{l}\text { First Language of the } \\
\text { Respondents }\end{array}$} & \multirow[t]{2}{*}{ Balochi } & Count & 71 & 135 & 43 & 249 \\
\hline & & $\begin{array}{l}\% \text { within first language of the } \\
\text { respondents }\end{array}$ & $28.5 \%$ & $54.2 \%$ & $17.3 \%$ & $100.0 \%$ \\
\hline & \multirow[t]{2}{*}{ Brahui } & Count & 27 & 62 & 29 & 118 \\
\hline & & $\begin{array}{l}\% \text { within first language of the } \\
\text { respondents }\end{array}$ & $22.9 \%$ & $52.5 \%$ & $24.6 \%$ & $100.0 \%$ \\
\hline & \multirow[t]{2}{*}{ Pashto } & Count & 51 & 70 & 21 & 142 \\
\hline & & $\begin{array}{l}\% \text { within first language of the } \\
\text { respondents }\end{array}$ & $35.9 \%$ & $49.3 \%$ & $14.8 \%$ & $100.0 \%$ \\
\hline & \multirow[t]{2}{*}{ Urdu } & Count & 13 & 17 & 5 & 35 \\
\hline & & $\begin{array}{l}\% \text { within first language of the } \\
\text { respondents }\end{array}$ & $37.1 \%$ & $48.6 \%$ & $14.3 \%$ & $100.0 \%$ \\
\hline & \multirow{2}{*}{$\begin{array}{l}\text { Other } \\
\text { Languages }\end{array}$} & Count & 11 & 12 & 4 & 27 \\
\hline & & $\begin{array}{l}\% \text { within first language of the } \\
\text { respondents }\end{array}$ & $40.7 \%$ & $44.4 \%$ & $14.8 \%$ & $100.0 \%$ \\
\hline
\end{tabular}


Source: Authors' survey

The above table shows that $28.5 \%$ of the Balochi speaking respondents were satisfied with the current NFC Award whereas $54.2 \%$ of such respondents had opposite viewpoint leaving the remaining $17.3 \%$ in a state of indifference. Within the Brahui speaking respondents, the ratio of satisfaction with respect to NFC Award remained 22.9\%, of dissatisfaction remained $52.5 \%$ whereas of indifference remained $24.6 \%$. Within the Pashto speaking respondents, the ratio of agreement to the statement of question remained $35.9 \%$, of disagreement remained $49.3 \%$ and of indifference remained $14.8 \% .37 .1 \%$ of the Urdu speaking and $40.7 \%$ of respondents having some other first language agreed to the statement of question whereas $48.6 \%$ of the Urdu speaking respondents and $44.4 \%$ of respondents having some other first language disagreed to the statement of question about NFC Award. The ratio of indifference remained $14.3 \%$ within the Urdu speaking respondents and $14.8 \%$ within respondents having some other first language. The preceding trends show that the ratio of dissatisfaction with respect to the current NFC Award is greater than that of satisfaction within all linguistic factions of Balochistan.

\subsubsection{Royalty Issue}

Balochistan has substantial reservoirs of natural gas in Sui and Pirkoh as well as premium minerals like chromium, copper, iron and coal (Breseeg, 2004). 49\% of the energy requirements of Pakistan were covered by natural gas while Balochistan fulfilled up to $80 \%$ of such requirement. Pakistan Petroleum Limited (PPL) had the operational control of Sui gas fields (the chief source of natural gas) along with five other gas fields in Balochistan and Sindh. The federal government held $78 \%$ of the shares of PPL (Pakistan: The Worsening Conflict in Balochistan, 2006). Natural Gas contributed US\$ 1.4 billion to the national exchequer but the average annual allocation to Balochistan was only US\$ 116 million. The people of Balochistan resented their insufficient share in terms of natural gas royalties from national exchequer (Rehman, 2006). The Baloch leadership, too, claims that the federal government never paid Balochistan the due share for its oil, gas and mineral resources. After the incorporation of 18th Amendment into the Constitution, the federal government believed that the issue had been resolved and the provinces are now getting an increased royalty share for their mineral resources. The matter was put before the general public in Balochistan through the present survey.

\begin{tabular}{|c|c|c|c|c|c|c|}
\hline \multicolumn{6}{|c|}{ Do you agree that Balochistan is getting proper royalty share for its mineral resources? } & \multirow[b]{2}{*}{ Total } \\
\hline & & & Agreed & Disagreed & Indifferent & \\
\hline \multirow{10}{*}{$\begin{array}{l}\text { First Language of the } \\
\text { Respondents }\end{array}$} & \multirow{2}{*}{ Balochi } & Count & 26 & 214 & 9 & 249 \\
\hline & & $\begin{array}{l}\% \text { within first language of the } \\
\text { respondents }\end{array}$ & $10.4 \%$ & $85.9 \%$ & $3.6 \%$ & $100.0 \%$ \\
\hline & \multirow[t]{2}{*}{ Brahui } & Count & 5 & 105 & 8 & 118 \\
\hline & & $\begin{array}{l}\% \text { within first language of the } \\
\text { respondents }\end{array}$ & $4.2 \%$ & $89.0 \%$ & $6.8 \%$ & $100.0 \%$ \\
\hline & \multirow[t]{2}{*}{ Pashto } & Count & 23 & 118 & 1 & 142 \\
\hline & & $\begin{array}{l}\text { \% within first language of the } \\
\text { respondents }\end{array}$ & $16.2 \%$ & $83.1 \%$ & $0.7 \%$ & $100.0 \%$ \\
\hline & \multirow[t]{2}{*}{ Urdu } & Count & 2 & 28 & 5 & 35 \\
\hline & & $\begin{array}{l}\text { \% within first language of the } \\
\text { respondents }\end{array}$ & $5.7 \%$ & $80.0 \%$ & $14.3 \%$ & $100.0 \%$ \\
\hline & \multirow{2}{*}{\begin{tabular}{|l|} 
Other \\
Languages
\end{tabular}} & Count & 1 & 25 & 1 & 27 \\
\hline & & $\begin{array}{l}\text { \% within first language of the } \\
\text { respondents }\end{array}$ & $3.7 \%$ & $92.6 \%$ & $3.7 \%$ & $100.0 \%$ \\
\hline
\end{tabular}

\section{Source: Authors' survey}

The data in the above table tells that only $10.4 \%$ of the Balochi, $4.2 \%$ of the Brahui, $16.2 \%$ of the Pashto, $5.7 \%$ of the Urdu speaking respondents and $3.7 \%$ of respondents having some other first language were of the opinion that Balochistan is getting proper amount in terms of royalty share for its mineral resources whereas $85.9 \%$ of respondents having Balochi, $89.0 \%$ of respondents having Brahui, $83.1 \%$ of respondents having Pashto, $80.0 \%$ of respondents having Urdu and $92.6 \%$ of respondents having some other first language had opposite viewpoint about the royalty issue. The ratio of indifference about the issue in hand remained 3.6\% within the Balochi, $6.8 \%$ within the Brahui, 
$0.7 \%$ within the Pashto, $14.3 \%$ within the Urdu speaking respondents and $3.7 \%$ within respondents having some other first language. In this way, an overwhelming majority of respondents, irrespective of their linguistic affiliation, expressed their resentment about the insufficient amount of royalty paid to Balochistan.

\subsubsection{The Issue of the Development of Gwadar Port}

On September 6, 1958, the Prime Minister of Pakistan, Mr. Feroz Khan Noon, using his personal relations with the British Government, purchased the port of Gwadar for 3 million pounds from Sultan of Muscat and Oman (Purchase of Gwadar, 2018). The price seemed higher at that time; nevertheless later developments showed that it was an act of statesmanship (Ahmad, 1992). In the present political and economic scenario of Pakistan (2017), it is worthmentioning that Lt. Col. Syed Iqbal Ahmad, a strategic expert, had pointed out in 1992 that China would like to see Balochistan a well developed province strongly integrated into Pakistan. According to him, China had shown special interest in strengthening Pakistan navy to guard the 700 miles coast line along the Makaran Coast (Ahmad, 1992). He further mentions that the USSR had approached the Government of Pakistan a decade ago to allow them to construct a road from Kandahar to one of the five ports of Makran Coast. They also offered to develop the ports of Gwadar and Pasni (Ahmad, 1992).

Jetly mentions that Gwadar was only 624 nautical miles from the strategic Strait of Hormuz. Musharraf regime dealt the Gwadar Port project on priority basis owing to its perceived image of a (would be) regional hub for transit and transshipment of goods for Afghanistan, Central Asia and the Middle East. The Balochs feared that, because of the development of the port, they were dispossessed of their land since the government acquired the land around the port at below par market value distributing it to the non-Baloch employees deployed at the project. The prices of land, too, soared higher and a 500 square yard plot with a previous cost of US\$130 shot up to US\$7,000 (Jetly, 2006). The monthly Herald reports the reservations of Sardar Ataullah Mengal about Gwadar Port in the following words:

"If there are jobs in Gwadar, people would flock there, Pakistanis and foreigners alike. With time, they would get the right to vote. The problem is that one Karachi in Gwadar is sufficient to turn the whole population of Balochistan into a minority. Gwadar will end up sending more members to the Parliament than the rest of Balochistan. We would lose our identity, our language, everything. That's why we are not willing to accept these mega projects (Ismail, 2004)."

There was a general perception in the entire country that the development of Gwadar Port is highly significant to improve the economy of Pakistan. The proposed China-Pakistan Economic Corridor (CPEC) revolves mainly around a well-structured Gwadar port. The general public in Balochistan perceives the development of Gwadar port as a sensitive issue. The present survey asked them whether or not the development of Gwadar port would benefit them.

\begin{tabular}{|c|c|c|c|c|c|c|}
\hline \multicolumn{6}{|c|}{ Do you agree that the development of Gwadar Port is beneficial for the local population of Balochistan? } & \multirow[b]{2}{*}{ Total } \\
\hline & & & Agreed & Disagreed & Indifferent & \\
\hline \multirow{10}{*}{$\begin{array}{l}\text { First Language of the } \\
\text { Respondents }\end{array}$} & \multirow[t]{2}{*}{ Balochi } & Count & 82 & 144 & 23 & 249 \\
\hline & & $\begin{array}{l}\% \text { within first language of the } \\
\text { respondents }\end{array}$ & $32.9 \%$ & $57.8 \%$ & $9.2 \%$ & $100.0 \%$ \\
\hline & \multirow[t]{2}{*}{ Brahui } & Count & 37 & 73 & 8 & 118 \\
\hline & & $\begin{array}{l}\% \text { within first language of the } \\
\text { respondents }\end{array}$ & $31.4 \%$ & $61.9 \%$ & $6.8 \%$ & $100.0 \%$ \\
\hline & \multirow[t]{2}{*}{ Pashto } & Count & 53 & 76 & 13 & 142 \\
\hline & & $\begin{array}{l}\% \text { within first language of the } \\
\text { respondents }\end{array}$ & $37.3 \%$ & $53.5 \%$ & $9.2 \%$ & $100.0 \%$ \\
\hline & \multirow[t]{2}{*}{ Urdu } & Count & 19 & 13 & 3 & 35 \\
\hline & & $\begin{array}{l}\% \text { within first language of the } \\
\text { respondents }\end{array}$ & $54.3 \%$ & $37.1 \%$ & $8.6 \%$ & $100.0 \%$ \\
\hline & \multirow{2}{*}{\begin{tabular}{|l} 
Other \\
Languages
\end{tabular}} & Count & 14 & 12 & 1 & 27 \\
\hline & & $\begin{array}{l}\% \text { within first language of the } \\
\text { respondents }\end{array}$ & $51.9 \%$ & $44.4 \%$ & $3.7 \%$ & $100.0 \%$ \\
\hline
\end{tabular}


Source: Authors' survey

The above table details that only $32.9 \%$ of people with Balochi as their first language considered that its development would benefit the local population of Balochistan whereas $57.8 \%$ of such respondents opposed that viewpoint leaving the remaining $9.2 \%$ in a state of indifference about the issue in hand. $31.4 \%$ of respondents who had Brahui as their first language agreed that the Port would be beneficial for Balochistan, $61.9 \%$ of such respondents disagreed and $6.8 \%$ remained indifferent about the matter. In the case of Pashto speaking respondents, the ratio of agreement with respect to issue of Gwadar Port remained 37.3\% which was a bit higher than the Balochi and the Brahui speaking people. $53.5 \%$ of Pashtun respondents disagreed about the statement of the question whereas $9.2 \%$ of such respondents remained indifferent. 54.3\% of Urdu speaking respondents agreed that Gwadar Port should be developed, $37.1 \%$ disagreed and $8.6 \%$ remained indifferent. Within the category of respondents having some other first language, the ratio of agreement remained $51.9 \%$, of disagreement remained $44.4 \%$ and of indifference remained $3.7 \%$. Hence, only the majority of the Urdu speaking respondents and respondents with first language other than Balochi, Brahui, Pashto and Urdu had positive opinion about development of Gwadar port whereas majority of respondents having Balochi, Brahui or Pashto as their first language disapproved such development.

\subsubsection{Electoral System of Pakistan}

The capability of the political system to help people in finding their genuine representatives and leadership definitely increases the satisfaction level of the general public. Preparation of electoral rolls, delimitation of electoral boundaries, formulating the rules and procedures and finally the conduct of free and fair polls are some of the basic ingredients of any prospering political system. While designing the survey, it was felt necessary to understand the view of the people of Balochistan about the present electoral system of Pakistan; they were asked whether or not the same is helping them to find their genuine representatives.

\begin{tabular}{|c|c|c|c|c|c|c|}
\hline \multicolumn{6}{|c|}{ Do you agree that the present electoral system in Pakistan is truly helping its people in finding their genuine representatives? } & \multirow[b]{2}{*}{ Total } \\
\hline & & & Agreed & Disagreed & Indifferent & \\
\hline \multirow{10}{*}{$\begin{array}{l}\text { First Language of the } \\
\text { Respondents }\end{array}$} & \multirow{2}{*}{ Balochi } & Count & 28 & 184 & 37 & 249 \\
\hline & & $\begin{array}{l}\% \text { within first language of the } \\
\text { respondents }\end{array}$ & $11.2 \%$ & $73.9 \%$ & $14.9 \%$ & $100.0 \%$ \\
\hline & \multirow[t]{2}{*}{ Brahui } & Count & 5 & 97 & 16 & 118 \\
\hline & & $\begin{array}{l}\% \text { within first language of the } \\
\text { respondents }\end{array}$ & $4.2 \%$ & $82.2 \%$ & $13.6 \%$ & $100.0 \%$ \\
\hline & \multirow[t]{2}{*}{ Pashto } & Count & 36 & 87 & 19 & 142 \\
\hline & & $\begin{array}{l}\% \text { within first language of the } \\
\text { respondents }\end{array}$ & $25.4 \%$ & $61.3 \%$ & $13.4 \%$ & $100.0 \%$ \\
\hline & \multirow[t]{2}{*}{ Urdu } & Count & 6 & 25 & 4 & 35 \\
\hline & & $\begin{array}{l}\% \text { within first language of the } \\
\text { respondents }\end{array}$ & $17.1 \%$ & $71.4 \%$ & $11.4 \%$ & $100.0 \%$ \\
\hline & \multirow{2}{*}{$\begin{array}{l}\text { Other } \\
\text { Languages }\end{array}$} & Count & 13 & 13 & 1 & 27 \\
\hline & & $\begin{array}{l}\% \text { within first language of the } \\
\text { respondents }\end{array}$ & $48.1 \%$ & $48.1 \%$ & $3.7 \%$ & $100.0 \%$ \\
\hline
\end{tabular}

Source: Authors' survey

The data in the above table explains that only $11.2 \%$ of the Balochi speaking respondents favored the electoral system currently prevalent in Pakistan while $73.9 \%$ of such respondents opposed it leaving the remaining $14.9 \%$ of such respondents in a state of indifference. Similarly, only $4.2 \%$ of the Brahui speaking respondents agreed to the statement of question, $82.2 \%$ disagreed and $13.6 \%$ remained indifferent. Moreover, $25.4 \%$ of the Pashto, $17.1 \%$ of the Urdu speaking and $48.1 \%$ of respondents with some other first language expressed their trust over the prevalent electoral system whereas $61.3 \%$ of the Balochi, $71.4 \%$ of the Urdu speaking and $48.1 \%$ of respondents from other linguistic groups were against that opinion. The ratio of indifference remained $13.4 \%$ within the Pashto, $11.4 \%$ within the Urdu speaking and 3.7\% within respondents from other linguistic groups. The net result is that only the respondents who had first language other than Balochi, Brahui, Pashto and Urdu believed up to some extent in the capability of the current electoral system to help people finding their genuine representatives whereas majority of all other linguistic 
groups opposed that viewpoint.

\subsubsection{Youth of Balochistan and Economic Insecurity}

The youth in Punjab, Sindh and Khyber Pakhtunkhwa normally had better opportunities to earn money after completing their education and entering into professional life. In that perspective, the next question was of a sensitive nature which asked about the comparative economic opportunities available to the youth of Balochistan in terms of trade and employment.

\begin{tabular}{|c|c|c|c|c|c|c|}
\hline \multicolumn{6}{|c|}{$\begin{array}{l}\text { Do you agree that the youth of Balochistan feel themselves economically more insecure than the youth of other provinces of } \\
\text { Pakistan? }\end{array}$} & \multirow[b]{2}{*}{ Total } \\
\hline & & & Agreed & Disagreed & Indifferent & \\
\hline \multirow{10}{*}{$\begin{array}{l}\text { First Language of the } \\
\text { Respondents }\end{array}$} & \multirow[t]{2}{*}{ Balochi } & Count & 162 & 59 & 28 & 249 \\
\hline & & $\begin{array}{l}\% \text { within first language of the } \\
\text { respondents }\end{array}$ & $65.1 \%$ & $23.7 \%$ & $11.2 \%$ & $100.0 \%$ \\
\hline & \multirow[t]{2}{*}{ Brahui } & Count & 77 & 25 & 16 & 118 \\
\hline & & $\begin{array}{l}\% \text { within first language of the } \\
\text { respondents }\end{array}$ & $65.3 \%$ & $21.2 \%$ & $13.6 \%$ & $100.0 \%$ \\
\hline & \multirow[t]{2}{*}{ Pashto } & Count & 95 & 31 & 16 & 142 \\
\hline & & $\begin{array}{l}\% \text { within first language of the } \\
\text { respondents }\end{array}$ & $66.9 \%$ & $21.8 \%$ & $11.3 \%$ & $100.0 \%$ \\
\hline & \multirow[t]{2}{*}{ Urdu } & Count & 18 & 15 & 2 & 35 \\
\hline & & $\begin{array}{l}\% \text { within first language of the } \\
\text { respondents }\end{array}$ & $51.4 \%$ & $42.9 \%$ & $5.7 \%$ & $100.0 \%$ \\
\hline & \multirow{2}{*}{$\begin{array}{l}\text { Other } \\
\text { Languages }\end{array}$} & Count & 23 & 2 & 2 & 27 \\
\hline & & $\begin{array}{l}\% \text { within first language of the } \\
\text { respondents }\end{array}$ & $85.2 \%$ & $7.4 \%$ & $7.4 \%$ & $100.0 \%$ \\
\hline
\end{tabular}

\section{Source: Authors' survey}

The trends in the public opinion about the economic insecurity of the youth of Balochistan portrayed that $65.1 \%$ of the Balochi, $65.3 \%$ of the Brahui, $66.9 \%$ of the Pashto, $51.4 \%$ of the Urdu speaking and $85.2 \%$ of respondents having some other first language agreed that there existed such feelings of insecurity. The ratio of disagreement about the statement of question remained 23.7\% within the Balochi, 21.2\% within the Brahui, 21.8\% within the Pashto, $42.9 \%$ within the Urdu speaking respondents and $7.4 \%$ within respondents having some other first language. The ratio of indifference remained 11.2\% within the Balochi, 13.6\% within the Brahui, $11.3 \%$ within the Pashto, 5.7\% within the Urdu speaking respondents and $7.4 \%$ within respondents having some other first language. These results show that only the Urdu speaking respondents believe up to some extent that the youth of Balochistan had fewer apprehensions about the economic insecurity of the youth of Balochistan whereas all other linguistic factions of the respondents had opposite viewpoint.

\subsubsection{Federal Form of Government and the People of Balochistan}

The last question of the survey was directly related to the functioning of federal form of government in Pakistan. The satisfaction level of the people of Balochistan about working of Pakistan as a federation was checked through this segment.

\begin{tabular}{|c|c|c|c|c|c|c|}
\hline \multicolumn{6}{|c|}{$\begin{array}{c}\text { Do you agree that the federal form of government in Pakistan has been successful enough to provide equal opportunities to the } \\
\text { people of Balochistan? }\end{array}$} & \multirow[b]{2}{*}{ Total } \\
\hline & & & Agreed & Disagreed & Indifferent & \\
\hline \multirow{4}{*}{$\begin{array}{l}\text { First Language of the } \\
\text { Respondents }\end{array}$} & \multirow{2}{*}{ Balochi } & Count & 25 & 198 & 26 & 249 \\
\hline & & $\begin{array}{l}\% \text { within first language of the } \\
\text { respondents }\end{array}$ & $10.0 \%$ & $79.5 \%$ & $10.4 \%$ & $100.0 \%$ \\
\hline & \multirow[t]{2}{*}{ Brahui } & Count & 10 & 85 & 23 & 118 \\
\hline & & $\begin{array}{l}\% \text { within first language of the } \\
\text { respondents }\end{array}$ & $8.5 \%$ & $72.0 \%$ & $19.5 \%$ & $100.0 \%$ \\
\hline
\end{tabular}




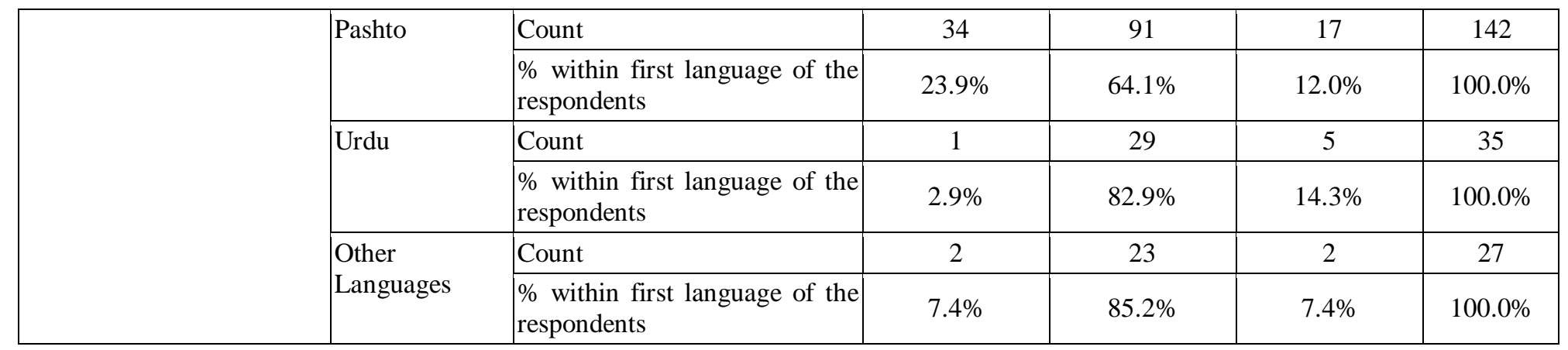

Source: Authors' survey

The above table details that only $10 \%$ of the Balochi, $8.5 \%$ of the Brahui, $23.9 \%$ of the Pashto, $2.9 \%$ of the Urdu speaking and $7.4 \%$ of respondents having some other first language were satisfied with the working of federal form of government in Pakistan. The ratio of dissatisfaction about the said theme remained $79.5 \%$ within the Balochi, $72 \%$ within the Brahui, $64.1 \%$ within the Pashto, $82.9 \%$ within the Urdu speaking and $85.2 \%$ within respondents from other linguistic groups. 10.4\% of the Balochi, $19.5 \%$ of the Brahui, 12\% of the Pashto, 14.3\% of the Urdu speaking and $7.4 \%$ of respondents from other linguistic groups remained indifferent. Hence, it may safely be concluded that a vast majority of respondents, irrespective of their linguistic affiliation, did not believe in the success of the federal form of government in Pakistan.

\section{Conclusion}

The survey established that majority of the people of Balochistan have some basic grievances about the present sociopolitical and economic structure of Pakistan; despite some mutual distrust, the major communities of Balochistan i.e. the Balochs, the Brahuis and the Pashtuns had a shared opinion about these grievances. The federal form of government is bound to provide equal opportunities to all the constituting units whereas majority of the people of Balochistan think that federation of Pakistan did not provide them equal opportunities to progress and prosper. The limit of the internal autonomy conferred on Balochistan has remained controversial since the very beginning (1947) when the Balochs were demanding for a self-sufficient State of Kalat but denied by the State of Pakistan. Despite the much pronounced 18th constitutional amendment (2010) which was incorporated into the constitution of 1973 by the former government of Pakistan Peoples Party wherein it was claimed that all the constituting units of the federation of Pakistan had been conferred with sufficient internal autonomy, the people of Balochistan are still not satisfied with the extent of politico-administrative autonomy provided to the province. Furthermore, the people of Balochistan were dissatisfied with the performance of state bureaucracy as well as with the prevalent electoral system of Pakistan. They also demanded that Balochistan should be given proper representation in all departments of the federal government.

The section of the survey related to economic issues presented a similar picture of financial deprivation and exploitation of the people of the province who were not satisfied with the amount of funds allocated to Balochistan after the Balochistan Package and 7th NFC Award of 2009 since their socio-economic conditions did not improve after almost seven years of the approval of said Award. The majority of the respondents disagreed that the province of Balochistan is getting proper share in terms of royalty for its mineral resources. They also feel that like other mega projects, development of Gwadar Port, too, would ultimately favor other units of the federation of Pakistan since they had been deprived from the benefits of natural gas deposits from Sui. They demanded that Balochistan should have the decisive role in decision making regarding Gwadar Mega Project where out of the total eleven members of the Board of Directors, only two belonged to Balochistan in 2005-6. They were in favor of providing job opportunities to the locals on priority basis in all mega projects. They further demanded that all amounts due in terms of gas royalty should immediately be released to the province. The youth in Balochistan are feeling that they are economically insecure as compared to youth of other regions.

Keeping in view the nature of problems faced by people of Balochistan, it may be recommended here that the elite in Pakistan must recognize the necessity of power sharing and the federal structure of Pakistan should be modified in a way to ensure rights of the provinces and accommodate various ethnic identities in the decision making process at the federal level. 


\section{References}

"7th NFS Award Signed in Gwadar", Dawn, December 31, 2009, accessed July 14, 2018, https://www.dawn.com/news/856981

"Pakistan: The Worsening Conflict in Balochistan". (2006), Brussels: International Crisis Group. Asia Report No. 119, accessed December 18, 2018, https://www.crisisgroup.org/asia/south-asia/pakistan/pakistan-worseningconflict-Balochistan

Ahmad, S.I. (1992). Balochistan: Its Strategic Importance. Karachi: Royal Book Company.

Ali, S. (1988). Nation Building Development and Administration: A Third World Perspective. Lahore: Aziz Publishers.

Breseeg, T.M. (2004). Baloch Nationalism: Its Origin and Development. Karachi. Royal Book Company.

Hicks, U. et al.(1961) Federalism and Economic Growth in Under-developed Countries, London: George Allen \& Unwin.

Hussain, A, et al, (2003), Poverty, Growth and Governance, Karachi: Oxford University Press

I A Rehman, (2006, January 15)“An Anti-Federation Mindset, The News,

Ismail, B. (2004, August) "Mega Projects are a Conspiracy to Turn the Balochis into a minority in their Homeland," (PP.51-52) An interview with Sardar Akhtar Mengal, The Herald.

Jetly, R. (October 2006). Re-emergence of The Baloch Movement in Pakistan, Institute of South Asian Studies,15, pp. $1-18$

Khalid, N.A. (2000), Mega Projects are a Conspiracy to Turn the Balochis into a minority in their Homeland, Lahore: Career Books

Pakistan Bureau of Statistics, Government of Pakistan, (1998), Area, Population, Density and Urban/Rural Proportion, accessed June 19, 2019, http://www.pbs.gov.pk/content/area-population-density-and-urbanruralproportion

Purchase of Gwadar, (2018, December 18), The Dawn, Accessed from https://www.dawn.com/news/1452133

Report of the National Finance Commission 2009 Government of Pakistan", accessed May 18, 2018, http://www.finance.gov.pk/nfc/reportofthenfc_2009.pdf 